\title{
Pengaruh Pendekatan Pembelajaran dan Gaya Belajar Terhadap Hasil Belajar Sejarah Siswa
}

\author{
Oleh : Jumardi \\ Pendidikan Sejarah, PPs UNJ \\ email : pps12jumardi@yahoo.com
}

\begin{abstract}
The aim of the study is to reveal the empirical data about the effect of learning approach and and learning styles on the outcome of history learning of SMA Negeri 35 Jakarta The methodology used is the experimental method with a $2 \times 2$ factorial design. Data analysis performed by using two way variance analysis. The findings of the study demonstrated: 1) The history learning outcome of the students who take the teaching methods CTL was higher than students who take conventional teaching methods. 2) The history learning outcome between students who have a visual learning style was higher than students who have auditory learning style. 3) There is an interaction effect between learning approach and learning style of the history learning outcome. 4) The history learning outcome of the students who take the teaching approach of CTL and have a visual learning style higher than students who take conventional teaching approach and have a visual learning style. 5) The history learning outcome of the students who take the teaching approach of CTL and auditory learning style is lower than students who take conventional teaching approach and have auditory learning styles. 6) The history learning outcome of the students who take the teaching approach of CTL and have a visual learning style was higher than students who take the teaching approach of CTL and have auditory learning styles. 7) The history learning outcome of the students who take conventional teaching approach and have a visual learning style is lower than students who take conventional teaching approach and have auditory learning styles
\end{abstract}

Keywords : Learning approach, learning style and history learning outcome.

\begin{abstract}
Abstrak
Tujuan penelitian ini untuk memperoleh data tentang pengaruh pendekatan pembelajaran dan gaya belajar terhadap hasil belajar sejarah. Dalam penelitian ini, siswa diberi pendekatan pembelajaran CTL dan konvensional, dengan memperhatikan gaya belajar visual dan gaya belajar auditori. Pendekatan penelitian menggunakan pendekatan eksperimen disain faktorial $2 \times 2$. Hasil penelitian memperlihatkan bahwa hasil belajar siswa yang diberi pendekatan pembelajaran CTL lebih tinggi dari pendekatan pembelajaran konvensional; hasil pembelajaran siswa dengan gaya belajar visual lebih tinggi dari gaya belajar auditori. Ada interaksi antara pendekatan pembelajaran dengan gaya belajar. Hasil pembelajaran siswa yang diberi pendekatan pembelajaran CTL dan memiliki gaya belajar visual yang lebih tinggi dari hasil belajar sejarah siswa yang diberi pendekatan pembelajaran konvensional dan memiliki gaya belajar visual. Hasil belajar siswa yang diberi pendekatan pembelajaran CTL dan memiliki gaya belajar auditori lebih rendah daripada siswa yang diberi pendekatan pembelajaran konvensional dan memiliki gaya belajar auditori. Hasil pembelajaran siswa yang yang diberi pendekatan pembelajaran CTL dan memiliki gaya belajar visual yang lebih tinggi daripada siswa yang diberi pembelajaran pendekatan CTL dan memiliki gaya belajar auditori. Hasil pembelajaran siswa yang diberi pendekatan pembelajaran konvensional dan memiliki gaya belajar visual lebih rendah daripada siswa yang diberi pendekatan pengajaran konvensional dan memiliki gaya belajar auditori.
\end{abstract}

Kata kunci : hasil belajar sejarah, pendekatan pembelajaran dan gaya belajar 


\section{Pendahuluan}

Memiliki jiwa kepahlawanan, rela berkorban, saling menghormati, mampu bekerja sama, dan tumbuh kembangnya karakter bangsa adalah bebarapa hal yang hendak dicapai dalam tujuan pembelajaran sejarah sehingga seluruh materi ajar dapat membawa bermanfaat bagi siswa dalam kehidupan nyata. Peran pendidikan sejarah sangat dibutuhkan dalam pembentukan karakter guna mengantisipasi tantangan global dan berbagai gejolak disintegrasi yang melanda Indonesia akhir-akhir ini. Pengalaman sejarah membuktikan karakter (sikap nasionalisme) mampu membangkitkan dinamika sosial di masa lalu. Sikap nasionalisme sebagai salah satu karakter yang dimiliki rakyat Indonesia mampu mengantarkan bangsa menuju kemerdekaan di tengah keterbelakangan pengetahuan rakyat Indonesia.

Peran pendidikan sejarah saat ini patut dipertanyakan karena karakter yang dimiliki bangsa menunjukkan kerapuhan. Dalam Peraturan Menteri Pendidikan Nasional Republik Indonesia Nomor 22 tahun 2006, mata pelajaran Sejarah memiliki arti strategis untuk pembentukan watak dan peradaban bangsa yang bermartabat serta pembentukan manusia Indonesia yang memiliki rasa kebangsaan dan cinta tanah air.

Berkaitan dengan hal tersebut, Harian Kompas tanggal 9 Juli 2010 melakukan jajak pendapat tentang setuju atau tidaknya pelajaran sejarah sebagai pembentuk karakter siswa terhadap 775 responden. Hasilnya sebagai berikut; $90,6 \%$ responden menyatakan setuju bahwa pembelajaran sejarah berperan membentuk karakter (watak anak bangsa), $7,2 \%$ menyatakan tidak setuju, dan 2,2\% menjawab tidak tahu. (Palupi Panca AstutiKompas online: 2014;1). Hasil jajak pendapat ini mencerminkan bahwa masyarakat Indonesia sadar akan pentingnya pembelajaran sejarah bagi tumbuhnya karakter siswa serta berkontribusi terhadap perkembangan intelektual, sikap, dan moral dari setiap individu siswa sebagai anggota masyarakat
(Eveline Siregar dan Hartini Nara;2010;1416). Terkait dengan pembelajaran sejarah , hasil jajak pendapat Kompas terhadap 775 responden tentang kendala pembelajaran sejarah disekolah menjelaskan, 1) $52 \%$ menjawab terkendala pendekatan pembelajaran konvensional, 2) 17,7\% menjawab terkendala buku teks yang terbatas dan mahal harganya, 3) $12,3 \%$ menjawab materi pelajaran yang tidak relevan, 4) $2 \%$ terkendala siswa, 5) $1 \%$ terkendala kurikulum sejarah yang kurang baik, 6) $15 \%$ menjawab tidak tahu (Palupi Panca Astuti-Kompas online: 2014;1).

Menurut Hamid Hasan terdapat beberapa pemaknaan terhadap pendidikan sejarah. Pertama, secara tradisional pendidikan sejarah dimaknai sebagai upaya mentransfer kemegahan bangsa di masa lampau kepada generasi muda. Dengan posisi yang demikian maka pendidikan sejarah adalah wahana bagi pewarisan nilai-nilai keunggulan bangsa. Melalui posisi ini pendidikan sejarah ditujukan untuk membangun kebanggaan bangsa dan pelestarian keunggulan tersebut. Kedua, pendidikan sejarah berkenaan dengan upaya memperkenalkan peserta didik terhadap disiplin ilmu sejarah. Oleh karena itu kualitas seperti berpikir kronologis, pemahaman sejarah, kemampuan analisis dan penafsiran sejarah, kemampuan penelitian sejarah, kemampuan analisis isu dan pengambilan keputusan (historical issues-analysis and decision making) menjadi tujuan penting dalam pendidikan sejarah (Hasan Hamid, 2007: 7).

Tujuan pelajaran sejarah dirancang bukan hanya untuk mengasah kompetensi pengetahuan siswa, tetapi juga membekali siswa dengan pengetahuan tentang dimensi ruang-waktu perjalanan sejarah Indonesia, keterampilan dalam menyajikan pengetahuan yang dikuasainya secara konkret dan abstrak, serta sikap menghargai jasa para pahlawan yang telah meletakkan pondasi bangunan negara Indonesia. Pembelajaran sejarah diharapkan membentuk pola pikir siswa yang sadar sejarah sebagai ciri masyarakat madani yaitu masyarakat yang demokratis, 
berkedaulatan dan menghormati hak asasi manusia.

Sejarah merupakan media pendidikan yang paling ampuh untuk memperkenalkan kepada siswa tentang bangsanya di masa lampau. Pendidikan sejarah juga mampu menopang karakter bangsa dengan kemampuan berpikir kritis analitis. Paradigma pembelajaran sejarah dengan pendekatan konvensional yang ditampilkan oleh sebahagian guru sering kali mengabaikan siswa karena siswa hanya bisa mendengarkan tanpa bisa terlibat langsung, termasuk memberikan sentuhan emosional. Salah satu pendekatan pembelajaran yang dapat memberikan hasil belajar yang baik dalam pembelajaran adalah pendekatan pembelajaran Contextual Teaching Learning (CTL).

Pendekatan pembelajaran CTL menurut Johnson dan Teachnet $(2013 ; 176)$ adalah proses pendidikan yang bertujuan membantu siswa melihat makna dalam materi akademik dengan menghubungkan pelajaran akademik dengan konteks kehidupan sehari-hari siswa, yaitu dengan konteks keadaan sosial dan budaya pribadi siswa Menurut Teachet, pengajaran dan pembelajaran kontekstual (CTL) membantu kita menghubungkan isi mata pelajaran dengan situasi dunia nyata dan memotivasi siswa membuat hubungan antara pengetahuan dan aplikasi dalam kehidupan siswa sebagai anggota keluarga, masyarakat, dan pekerja dan terlibat dalam kerja keras yang requiers belajar."

Pendekatan pembelajaran CTL menghendaki keterlibatan siswa secara penuh agar dapat menghubungkan materi ajar dengan kehidupan nyata. Hal ini penting diterapkan agar informasi yang diterima tidak hanya disimpan dalam memori jangka pendek, tetapi dapat disimpan dalam memori jangka panjang. Pendekatan Pembelajaran CTL membantu guru untuk mengembangkan daya pikir kritis siswa untuk setiap materi ajar. Karakteristik pendekatan pembelajaran CTL meliputi kerjasama, siswa aktif, kritis, dan saling menunjang sehingga dapat meningkatkan hasil belajar.
Jenkins dan Unwin menyatakan bahwa hasil belajar merupakan pengalamanpengalaman belajar yang diperoleh siswa dalam bentuk kemampuan tertentu (Hamzah B Uno;2009;19). Cronbach dalam Sardiman menjelaskan bahwa hasil belajar ditunjukkan dengan adanya perubahan perilaku atau sikap sebagai hasil pengalaman (Sardiman, A.M 2007:20). Hasil belajar menurut Gagne dan Briggs dalam Jamil (2013;37) adalah kemampuan yang dimiliki siswa sebagai akibat perbuatan belajar dan dapat diamati melalui penampilan siswa (learner's performance). Reigeluth mengemukakan bahwa hasil belajar adalah suatu kinerja yang diindikasikan sebagai suatu kemampuan yang telah diperoleh. (Ibid:37)

Bloom menjelaskan tentang hasil belajar adalah memiliki kemampuan kognitif, afektif dan psikomotorik. (Agus Suprijono;2013;6). Hasil belajar sejarah tidak semata ditentukan oleh pendekatan pembelajarannya saja, tetapi perlu juga gaya belajar siswa. Gaya belajar merupakan kebiasaan belajar siswa untuk menerima informasi sehingga mampu memaknai setiap materi yang diberikan dan menyajikan kembali serta dapat memecahkan permasalahan pembelajaran. Drummond mendefinisikan gaya belajar sebagai model pilihan individu dan kondisi yang diinginkan dalam pembelajaran.

Bobbi Deporter \& Mike Hernacki (2013:110120), mengatakan bahwa gaya Belajar adalah kemampuan menyerap informasi dengan mudah dan bagaimana mengatur dan mengolah informasi tersebut. Lebih lanjut, Bobbi Deporter \& Mike Hernacki mengemukakan tiga jenis gaya belajar berdasarkan modalitas yang digunakan individu dalam memproses informasi (perceptual modality) yaitu gaya belajar visual, gaya belajar auditorial dan gaya belajar kinestetik. Dale H.Schunk (2012;478) menjelaskan, bahwa gaya belajar adalah perbedaan individu yang secara konsisten dalam mengatur dan memproses informasi yang berbeda.

James dan Gardner dalam M. Nur Ghufron (2013;42) berpendapat bahwa 
gaya belajar adalah cara yang kompleks di mana para siswa menganggap dan merasa paling efektif dan efisien dalam memproses, menyimpan dan memanggil kembali apa yang telah dipelajari.

Drummond mendefinisikan gaya belajar sebagai model pilihan individu dan kondisi yang diinginkan dalam pembelajaran (Havid Ardi;2007;1), sedangkan Keefe dalam M. Nur Ghufron menjelaskan bahwa gaya belajar faktor-faktor kognitif, afektif, dan fisiologis yang menyajikan beberapa indikator yang relatif stabil tentang bagaimana para siswa merasa berhubungan dengan lainnya dan bereaksi terhadap lingkungan belajar. (M. Nur Ghufron;Op Cit;43)

Perhatian penelitian ini adalah gaya belajar visual dan auditorial. Siswa yang memiliki kecenderungan gaya belajar visual lebih senang melihat apa yang sedang dipelajari melalui gambar/visualisasi, membaca buku, atau berdiskusi. Apabila seseorang menjelaskan sesuatu kepada siswa yang memiliki kecenderungan gaya belajar visual, siswa akan menciptakan gambaran mental tentang apa yang disampaikan dan diterima. Sedangkan siswa yang memiliki kecenderungan gaya belajar auditorial akan belajar lebih baik dengan mendengarkan. Siswa menikmati saat-saat mendengarkan apa yang disampaikan oleh guru. Siswa yang memiliki gaya belajar audirtorial cenderung tidak mudah konsentrasi.

Gaya belajar dan pendekatan pembelajaran sangat menentukan hasil belajar siswa. Hasil belajar optimal akan diperoleh apabila beragam perbedaan seperti kebiasaan, minat, dan gaya belajar pada siswa diakomodasi oleh guru melalui pilihan pendekatan pembelajaran dan kesesuaian materi ajar dengan gaya belajar siswa. Untuk itu diperlukan keterampilan guru dalam mendisain pembelajaran dengan keanekaragaman siswa. Pendekatan yang tepat dan ditunjang gaya belajar yang baik, pembelajaran akan lebih bermakna dan siswa mengerti relevansi apa yang dipelajari di sekolah dengan situasi kehidupan nyata.
Penelitian yang relevan ditulis oleh Ningrum, Sudiana dan Yudana menyatakan bahwa adanya pengaruh dan hasil belajar siswa yang diberi pendekatan pembelajaran CTL dengan memperhatikan gaya belajar menunjukkan hasil lebih baik.

\section{Metode Penelitian}

Pendekatan penelitian menggunakan pendekatan eksperimen dengan rancangan desain factorial by level $2 \times 2$. Penelitian terdiri dari dua variabel bebas dan satu variabel terikat. Sebagai variabel bebas 1 adalah pendekatan pembelajaran (A ) dan sebagai variabel bebas 2 gaya belajar ( B ). Variabel terikat dalam penelitian ini adalah hasil belajar ( $Y$ ).

Variabel bebas 1 yaitu pendekatan pembelajaran yaitu pendekatan pembelajaran CTL $\left(A_{1}\right)$ dan pendekatan pembelajaran konvensional $\left(\mathrm{A}_{2}\right)$ sedangkan variabel bebas 2 adalah gaya belajar visual $\left(\mathrm{B}_{1}\right)$ dan gaya belajar auditorial $\left(\mathrm{B}_{2}\right)$. Disain faktorial by level $2 \times 2$ dengan matrik seperti dibawah ini

\section{Tabel Rancangan Eksperimen Disain Faktorial by Level $2 \times 2$}

\begin{tabular}{|c|c|c|}
\hline \multirow[b]{2}{*}{$\begin{array}{l}\text { Gaya } \\
\text { Belajar } \\
\text { (B) }\end{array}$} & \multicolumn{2}{|c|}{ Pendekatan Pembelajaran ( A ) } \\
\hline & $\begin{array}{l}\text { Pendekatan } \\
\text { Pembelajaran CTL } \\
\left(\mathrm{A}_{1}\right)\end{array}$ & $\begin{array}{l}\text { Pendekatan } \\
\text { Pembelajaran } \\
\text { Konvensional }\left(\mathrm{A}_{2}\right)\end{array}$ \\
\hline $\begin{array}{l}\text { Gaya } \\
\text { Belajar } \\
\text { Visual }\left(B_{1}\right)\end{array}$ & $\mathrm{A}_{1} \mathrm{~B}_{1}$ & $\mathrm{~A}_{2} \mathrm{~B}_{1}$ \\
\hline $\begin{array}{l}\text { Gaya } \\
\text { Belajar } \\
\text { Auditorial } \\
\left(\mathrm{B}_{2}\right)\end{array}$ & $\mathrm{A}_{1} \mathrm{~B}_{2}$ & $\mathrm{~A}_{2} \mathrm{~B}_{2}$ \\
\hline
\end{tabular}

Penelitian dilaksanakan di SMA Negeri 35 Jakarta Pusat pada bulan September 2013 hingga April 2014. Populasi pada penelitian ini adalah siswa kelas XI IPS yang berjumlah 120 siswa terbagi dalam 3 kelas IPS. Teknik pengambilan sampel yang digunakan yaitu teknik Random Sampling dengan mengambil secara acak 2 kelas yang terdiri dari 40 siswa. Sebelum diberi perlakuan siswa 
yang berada di dalam 2 kelas ini diberikan kuesioner untuk mendapatkan data skor gaya belajar. Perlakuan pada penelitian ini adalah kelas IPS ${ }_{3}$ diberi perlakuan menggunakan pendekatan pembelajaran CTL dan kelas IPS diberi perlakuan menggunakan pendekatan pembelajaran konvensional. Masing-masing kelas perlakuan terbagi atas dua gaya belajar yaitu siswa yang mempunyai gaya belajar visual dan siswa yang mempunyai gaya belajar auditorial.

\section{Teknik Analisis Data}

Pengujian hipótesis dalam penelitian ini digunakan teknik análisis varians dua jalur (ANAVA $2 \times 2$ ). Sebelum ANAVA terlebih dahulu dilakukan uji persyaratan análisis yaitu meliputi uji normalitas dengan uji Lilifors dan uji homogenitas varian dengan uji Bartlett. Hasil perhitungan uji lanjut memakai uji Tuckey dan dilakukan manakala ditemukan pengaruh interaksi antara pendekatan pembelajaran dan gaya belajar terhadap hasil belajar sejarah siswa SMA

\section{Hasil Penelitian dan Pembahasan}

Data penelitian untuk hasil belajar dikelompokkan ke dalam delapan kelompok data yakni:

1. Data siswa yang diberikan pendekatan pembelajaran CTL $\left(\mathrm{A}_{1}\right)$

2. Data siswa diberikan pendekatan pembelajaran konvesional $\left(\mathrm{A}_{2}\right)$

3. Data siswa yang memiliki gaya belajar visual $\left(\mathrm{B}_{1}\right)$

4. Data siswa yang memiliki gaya auditorial $\left(\mathrm{B}_{2}\right)$

5. Data siswa yang diberi pendekatan pembelajaran CTL dan memiliki gaya belajar visual $\left(\mathrm{A}_{1} \mathrm{~B}_{1}\right)$

6. Data siswa yang diberi pendekatan pembelajaran CTL dan memiliki gaya belajar auditorial. $\left(\mathrm{A}_{1} \mathrm{~B}_{2}\right)$

7. Data siswa yang diberi pendekatan pembelajaran konvensional dan memiliki gaya belajar visual. $\left(\mathrm{A}_{2} \mathrm{~B}_{1}\right)$

8. Data siswa diberi pendekatan pembelajaran konvensional yang memiliki gaya belajar auditorial $\left(\mathrm{A}_{2} \mathrm{~B}_{2}\right)$. Berikut tabel deskripsi data.

Tabel Deskripsi Data

\begin{tabular}{|c|c|c|c|c|c|c|c|c|c|}
\hline \multirow{2}{*}{ No } & \multirow{2}{*}{ Kelompok } & \multicolumn{7}{|c|}{ Data Statistik } & \multirow{2}{*}{ Rentang } \\
\cline { 3 - 10 } & & $\mathbf{n}$ & Max & Min & Mo & Me & $\overline{\mathbf{X}}$ & SDX & \\
\hline 1 & $\mathrm{~A}_{1}$ & 20 & 37 & 16 & 33.5 & 30.5 & 27.80 & 7.33 & 21 \\
\hline 2 & $\mathrm{~A}_{2}$ & 20 & 30 & 14 & 18.5 & 23.5 & 23.00 & 5.24 & 16 \\
\hline 3 & $\mathrm{~B}_{1}$ & 20 & 37 & 14 & 35.3 & 28.5 & 26.40 & 8.53 & 23 \\
\hline 4 & $\mathrm{~B}_{2}$ & 20 & 30 & 16 & 26.5 & 25.0 & 24.40 & 4.30 & 14 \\
\hline 5 & $\mathrm{~A}_{1} \mathrm{~B}_{1}$ & 10 & 37 & 31 & 35.3 & 34.9 & 34.40 & 1.90 & 6 \\
\hline 6 & $\mathrm{~A}_{1} \mathrm{~B}_{2}$ & 10 & 26 & 16 & 23.0 & 21.5 & 21.20 & 3.61 & 10 \\
\hline 7 & $\mathrm{~A}_{2} \mathrm{~B}_{1}$ & 10 & 24 & 14 & 18.0 & 18.3 & 18.40 & 2.80 & 10 \\
\hline 8 & $\mathrm{~A}_{2} \mathrm{~B}_{2}$ & 10 & 30 & 24 & 27.5 & 27.5 & 27.60 & 1.78 & 6 \\
\hline
\end{tabular}


Untuk rangkuman skor hasil belajar sejarah adalah sebagai berikut :

Tabel Rangkuman Skor Hasil Belajar Sejarah

\begin{tabular}{|c|c|c|c|}
\hline $\begin{array}{l}\text { Pendekatan } \\
\text { Pembelajaran }\end{array}$ & $\begin{array}{c}\text { Pendekatan } \\
\text { Pembelajaran } \\
\text { CTL (A) }\end{array}$ & $\begin{array}{c}\text { Pendekatan } \\
\text { Pembelajaran } \\
\text { Konvensional }\left(\mathrm{A}_{2}\right)\end{array}$ & Total \\
\hline Visual $\left(\mathrm{B}_{1}\right)$ & $\begin{aligned} \mathrm{n}_{1} & =10 \\
\Sigma \mathrm{X}_{1} & =344 \\
\Sigma \mathrm{X}_{1}^{2} & =11866 \\
\overline{\mathrm{X}_{1}} & =34,40\end{aligned}$ & $\begin{aligned} \mathrm{n}_{2} & =10 \\
\Sigma \mathrm{X}_{2} & =184 \\
\Sigma \mathrm{X}_{2}^{2} & =3456 \\
\overline{\mathrm{X}_{2}} & =18,40\end{aligned}$ & $\begin{aligned} \mathrm{n}_{\mathrm{b} 1} & =20 \\
\Sigma \mathrm{X}_{\mathrm{b} 1} & =528 \\
\Sigma \mathrm{X}_{\mathrm{b} 1}^{2} & =15322 \\
\overline{\mathrm{X}_{\mathrm{b} 1}} & =26,40\end{aligned}$ \\
\hline Auditorial $\left(\mathrm{B}_{2}\right)$ & $\begin{aligned} \mathrm{n}_{3} & =10 \\
\Sigma \mathrm{X}_{3} & =212 \\
\Sigma \mathrm{X}_{3}^{2} & =4612 \\
\overline{\mathrm{X}_{3}} & =21,20\end{aligned}$ & $\begin{aligned} \mathrm{n}_{4} & =10 \\
\Sigma \mathrm{X}_{4} & =276 \\
\Sigma \mathrm{X}_{4}^{2} & =7646 \\
\overline{\mathrm{X}_{4}} & =27,60\end{aligned}$ & $\begin{aligned} \mathrm{n}_{\mathrm{b} 2} & =20 \\
\Sigma \mathrm{X}_{\mathrm{b} 2} & =488 \\
\Sigma \mathrm{X}_{\mathrm{b} 2}^{2} & =12258 \\
\overline{\mathrm{X}_{\mathrm{b} 2}} & =24,40\end{aligned}$ \\
\hline Total & $\begin{aligned} \mathrm{n}_{\mathrm{k} 1} & =20 \\
\Sigma X_{\mathrm{k} 1} & =556 \\
\Sigma X_{\mathrm{k} 1}^{2} & =16478 \\
\overline{X_{\mathrm{k} 1}} & =27,80\end{aligned}$ & $\begin{aligned} \mathrm{n}_{\mathrm{k} 2} & =20 \\
\Sigma \mathrm{X}_{\mathrm{k} 2} & =460 \\
\Sigma \mathrm{X}_{\mathrm{k} 2}^{2} & =11102 \\
\overline{\mathrm{X}_{\mathrm{k} 2}} & =23,00\end{aligned}$ & $\begin{aligned} \mathrm{n}_{\mathrm{t}} & =40 \\
\Sigma \mathrm{X}_{\mathrm{t}} & =1016 \\
\Sigma \mathrm{X}_{\mathrm{t}}^{2} & =27580 \\
\overline{\mathrm{X}_{\mathrm{t}}} & =25,400\end{aligned}$ \\
\hline
\end{tabular}

Berdasarkan rancangan eksperimen yang telah disusun dalam penelitian ini, ada 8 kelompok hasil belajar yang akan dideskripsikan secara terpisah. Delapan kelompok tersebut adalah:

1. Hasil belajar sejarah yang diberikan pendekatan pembelajaran CTL

2. Hasil belajar dengan pendekatan konvensional

3. Hasil belajar sejarah siswa dengan gaya belajar visual

4. Hasil belajar sejarah siswa dengan gaya belajar auditorial
5. Hasil belajar sejarah siswa dengan gaya belajar visual yang diberi pendekatan pembelajaran CTL

6. Hasil belajar sejarah siswa dengan gaya belajar visual yang diberi pendekatan pembelajaran konvensional

7. Hasil belajar sejarah siswa dengan gaya belajar auditorial yang diberi pendekatan pembelajaran CTL

8. Hasil belajar sejarah siswa dengan gaya belajar auditorial yang diberi pendekatan pembelajaran konvensional. 
Tabel

Rangkuman Hasil Uji Normalitas (Liliefors) Data Hasil Belajar Sejarah

\begin{tabular}{|c|l|c|c|c|c|}
\hline No & Kelompok Data & $\mathbf{n}$ & $\mathbf{L}_{\mathbf{0}}$ & $\mathbf{L}_{\mathbf{t}(\alpha=0,05)}$ & Kesimpulan \\
\hline 1. & Kelompok $\mathrm{A}_{1}$ & 20 & 0,119 & 0,198 & Normal \\
\hline 2. & Kelompok $\mathrm{A}_{2}$ & 20 & 0,130 & 0,198 & Normal \\
\hline 3. & Kelompok $\mathrm{B}_{1}$ & 20 & 0,187 & 0,198 & Normal \\
\hline 4. & Kelompok $\mathrm{B}_{2}$ & 20 & 0,113 & 0,198 & Normal \\
\hline 5. & Kelompok $\mathrm{A}_{1} \mathrm{~B}_{1}$ & 10 & 0,124 & 0,280 & Normal \\
\hline 6. & Kelompok $\mathrm{A}_{2} \mathrm{~B}_{1}$ & 10 & 0,130 & 0,280 & Normal \\
\hline 7. & Kelompok $\mathrm{A}_{1} \mathrm{~B}_{2}$ & 10 & 0,157 & 0,280 & Normal \\
\hline 8. & Kelompok $\mathrm{A}_{2} \mathrm{~B}_{2}$ & 10 & 0,132 & 0,280 & Normal \\
\hline
\end{tabular}

Berdasarkan uji Liliefors didapat hasil perhitungan $\left(\mathrm{L}_{0}\right)$ untuk semua kelompok data lebih kecil dari nilai Liliefors tabel $\left(\mathrm{L}_{\mathrm{t}}\right)$. Dengan demikian kelompok sampel penelitian ini berasal dari populasi yang berdistribusi normal, sehingga persyaratan normalitas terpenuhi. Pengujian normalitas dilakukan dengan menggunakan uji Barlett pada taraf signifikansi $\alpha=0,05$; dimana $\mathrm{dk}(1-\mathrm{a})(\mathrm{k}-1)$ dengan kriteria apabila nilai hitung lebih kecil dari tabel maka varians semua kelompok bersifat homogen. Rangkuman hasil perhitungan pengujian homogenitas varians kelompok kombinasi perlakuan dapat dilihat pada tabel di bawah ini:

Tabel Rangkuman Hasil Pengujian Homogenitas Varians Kelompok Kombinasi Perlakuan

\begin{tabular}{|c|c|c|c|c|c|c|}
\hline Kelompok & $\begin{array}{c}\text { Varians } \\
\left(\sigma^{2}\right)\end{array}$ & $\begin{array}{c}\text { Varians } \\
\text { Gabungan } \\
\left(\sigma_{1}^{2}\right)\end{array}$ & Nilai B & $\mathrm{X}_{\mathrm{h}}{ }^{2}$ hitung & $\begin{array}{c}X_{\text {tabel }}^{2} \\
(0,05 ; 3) \\
\text { ct2 }\end{array}$ & Kesimpulan \\
\hline $\begin{array}{l}\mathrm{A}_{1} \\
\mathrm{~A}_{2} \\
\mathrm{~A}_{2}\end{array}$ & $\begin{array}{l}53,75 \\
27,47\end{array}$ & & & 1,96 & 3,12 & Homogen \\
\hline $\begin{array}{l}\mathrm{B}_{1} \\
\mathrm{~B}_{2}\end{array}$ & $\begin{array}{l}72,78 \\
28,46\end{array}$ & & & 2,56 & 3,12 & Homogen \\
\hline $\begin{array}{l}\mathrm{A}_{1} \mathrm{~B}_{1} \\
\mathrm{~A}_{2} \mathrm{~B}_{1} \\
\mathrm{~A}_{1} \mathrm{~B}_{2} \\
\mathrm{~A}_{2} \mathrm{~B}_{2}\end{array}$ & $\begin{array}{c}3,60 \\
13,07 \\
7,82 \\
3,16\end{array}$ & 6,91 & 30,22 & 6,07 & 7,81 & Homogen \\
\hline
\end{tabular}


Dari tabel terlihat bahwa $\chi_{\text {hitung }}^{2}$ adalah 6,91 dan $\chi_{\text {tabel }}^{2}$ adalah 7,81 dengan $\alpha=0,05$. Dengan demikian maka varians semua kombinasi perlakuan adalah homogen, sehingga persyaratan homogenitas terpenuhi. dilakukan uji lanjut dengan menggunakan Uji Tuckey. Rangkuman hasil perhitungan analisis varians (ANAVA) dua jalur dengan statistik F disajikan pada tabel berikut :

Tabel Rangkuman Hasil Perhitungan Analisis Varians (ANAVA) Dua Jalur

\begin{tabular}{|l|c|c|c|c|l|}
\hline \multicolumn{1}{|c|}{ Sumber Varians } & Db & JK & RK = JK/db & Fh = RKIRKD & Ft 0,05 \\
\hline $\begin{array}{l}\text { Pendekatan } \\
\text { Pembelajaran (A) }\end{array}$ & 1 & 230,40 & 230,40 & $33,338^{*}$ & 4,11 \\
\hline Gaya Belajar (B) & 1 & 40,00 & 40,00 & $5,788^{* *}$ & 4,11 \\
\hline Interaksi (A x B) & 1 & 1254,40 & 1254,40 & $181,505^{*}$ & 4,11 \\
\hline Perlakuan & 3 & 1524,80 & & & \\
\hline Kekeliruan (D) & 68 & 248,80 & 6,91 & & \\
\hline Total Dikoreksi (TR) & 71 & 1773,60 & & & \\
\hline
\end{tabular}

Tabel Rangkuman Keseluruhan Hasil Uji Tuckey

\begin{tabular}{|c|c|c|c|}
\hline $\begin{array}{c}\text { Kelompok yang } \\
\text { Dibandingkan }\end{array}$ & $\mathbf{Q}_{\text {hitung }}$ & $\mathbf{Q}_{\text {tabel }}$ & \multirow{2}{*}{ Kesimpulan } \\
\cline { 3 - 3 } & & $\boldsymbol{\alpha}=\mathbf{0 , 0 5}$ & \\
\hline $\mathrm{Q}_{1}: \mathrm{A}_{1}$ dan $\mathrm{A}_{2}$ & 8,17 & 3,15 & Tolak $\mathrm{H}_{0}$ \\
\hline $\mathrm{Q}_{2}: \mathrm{B}_{1}$ dan $\mathrm{B}_{2}$ & 3,40 & 3,15 & Tolak $\mathrm{H}_{0}$ \\
\hline \multicolumn{1}{|c|}{ (Interaksi) } & & & \\
$\mathrm{Q}_{3}: \mathrm{A}_{1} \mathrm{~B}_{1}$ dan $\mathrm{A}_{2} \mathrm{~B}_{2}$ & 11,57 & 3,15 & Tolak $\mathrm{H}_{0}$ \\
$\mathrm{Q}_{4}: \mathrm{A}_{1} \mathrm{~B}_{2}$ dan $\mathrm{A}_{2} \mathrm{~B}_{1}$ & 4,76 & 3,15 & Tolak $\mathrm{H}_{0}$ \\
\hline $\mathrm{Q}_{5}: \mathrm{A}_{1} \mathrm{~B}_{1}$ dan $\mathrm{A}_{2} \mathrm{~B}_{1}$ & 19,25 & 3,58 & Tolak $\mathrm{H}_{0}$ \\
\hline $\mathrm{Q}_{6}: \mathrm{A}_{1} \mathrm{~B}_{2}$ dan $\mathrm{A}_{2} \mathrm{~B}_{2}$ & 7,70 & 3,58 & Tolak $\mathrm{H}_{0}$ \\
\hline $\mathrm{Q}_{7}: \mathrm{A}_{1} \mathrm{~B}_{1}$ dan $\mathrm{A}_{1} \mathrm{~B}_{2}$ & 15,88 & 3,58 & Tolak $\mathrm{H}_{0}$ \\
\hline $\mathrm{Q}_{8}: \mathrm{A}_{2} \mathrm{~B}_{1}$ dan $\mathrm{A}_{2} \mathrm{~B}_{2}$ & 11,07 & 3,58 & Tolak $\mathrm{H}_{0}$ \\
\hline
\end{tabular}

\section{Pembahasan Hasil Penelitian}

Pertama, dari hasil analis varians (ANAVA) dua jalur diketahui bahwa $\mathrm{H}_{0}$ yang menyatakan hasil belajar siswa yang diberikan pendekatan pembelajaran CTL lebih rendah dari siswa yang diberikan pendekatan konvensional ditolak. Hal ini berarti hasil belajar sejarah yang diberikan pendekatan CTL lebih tinggi dari hasil belajar sejarah dengan pendekatan pembelajaran konvensional.

Pembelajaran dengan pendekatan pembelajaran CTL membuat siswa dapat 
menghubungkan atau mengkaitkan suatu peristiwa sejarah dimasa kini dengan peristiwa sejarah dalam materi ajar. Keunggulan dari pembelajaran CTL adalah berpusat pada siswa serta siswa lebih berpraktek dan cenderung tidak menghafal. Pada pendekatan pembelajaran CTL, siswa bekerja sama untuk mencapai tujuan pembelajaran. Siswa termotivasi meningkatkan penalaran dalam pembelajaran sehingga tumbuh kesadaran pentingnya pembelajaran sejarah yang berguna bagi masa depannya.

Guru juga dapat mengajak siswa untuk aktif menggunakan media pembelajaran selain bahan ajar, misalnya surat kabar, majalah atau pun internet. Penggunaan media selain bahan ajar memungkinkan siswa untuk dapat menghubungkan materi sejarah dengan kondisi nyata. Hal tersebut dilakukan untuk mencapai tujuan pembelajaran.

Dalam pendekatan pembelajaran konvensional, proses pembelajaran hanya terjadi satu arah. Siswa lebih terfokus hanya pada materi dan bahan ajar yang disampaikan guru. Keterlibatan siswa hanya saat ditanya atau pada saat diskusi singkat mengenai materi ajar. Hal tersebut bagi sebagian siswa sangat menyulitkan dalam pengembangan diri.

Kedua adalah tolak $\mathrm{H}_{0}$ yang menyatakan bahwa hasil belajar siswa yang memiliki gaya belajar visual lebih rendah daripada siswa yang memiliki gaya belajar auditorial. Ini menunjukkan bahwa hasil belajar siswa yang memiliki gaya belajar visual lebih tinggi dari siswa yang memiliki gaya belajar auditorial.

Siswa dengan gaya belajar visual cenderung aktif dalam mencari informasi yang berkaitan dengan materi ajar baik lewat buku ajar, surat kabar, internet. Kelebihan yang melekat pada gaya belajar juga lebih teliti dan mampu berkonsentrasi ketika dalam keadaan ramai. Berbeda dengan siswa dengan gaya belajar auditorial. Kekurangan yang melekat pada siswa dengan gaya belajar auditorial adalah kurang baik ketika membaca, mudah terganggu dengan keributan, sulit diam dalam waktu yang relatif lama.
Ketiga, terdapat pengaruh interaksi antara pendekatan pembelajaran dengan gaya belajar siswa terhadap hasil belajar sejarah siswa. Hasil uji tuckey adalah tolak $\mathrm{H}_{0^{\prime}}$ dimana $\mathrm{H}_{0}$ tidak terdapat pengaruh antara pendekatan pembelajaran dengan gaya belajar terhadap hasil belajar sejarah siswa dan $\mathrm{H}_{1}$ terdapat pengaruh antara pendekatan pembelajaran dengan gaya belajar terhadap hasil belajar sejarah siswa. Pemilihan pendekatan pembelajaran dan pemahaman guru tentang gaya belajar siswa mutlak diperlukan oleh setiap guru. Pendekatan pembelajaran (CTL dan Konvensional) berinteraksi dengan gaya belajar siswa (visual dan auditorial) sehingga berpengaruh terhadap hasil belajar siswa.

Keempat, Hipotesis keempat menyatakan bahwa hasil belajar sejarah siswa yang diberi pendekatan pembelajaran CTL dan memiliki gaya belajar visual lebih rendah dari hasil belajar sejarah siswa diberi pendekatan pembelajaran konvensional dan memiliki gaya belajar visual. Uji tuckey untuk hipotesis ke empat adalah tolak $\mathrm{H}_{0}$.

Hal ini berarti bahwa pendekatan pembelajaran CTL lebih tinggi hasil belajar sejarah untuk siswa yang memiliki gaya belajar visual. Pada pembelajaran CTL, siswa yang memiliki gaya belajar visual dapat mengaktifkan kemampuannya dengan belajar terbuka terhadap sumber belajar, sehingga hasil belajar yang diperoleh lebih tinggi. Berbeda bila diberikan pendekatan konvensional, siswa dengan gaya belajar visual cenderung bosan karena tidak mampu untuk memperkaya materi ajar dari sumber lain, serta tidak mampu mengembangkan pemikirannya.

Siswa dengan gaya belajar visual umumnya senang membaca dan memiliki kemampuan berbicara cepat. Pemilihan pendekatan pembelajaran CTL sangat membantu siswa yang memiliki gaya belajar visual.

Hipotesis kelima, hasil belajar sejarah antara siswa yang diberi pendekatan pembelajaran CTL dan memiliki gaya belajar auditorial lebih tinggi dari hasil belajar sejarah 
siswa yang diberi pendekatan pembelajaran konvensional dan memiliki gaya belajar auditorial. Uji tuckey untuk hipotesis kelima adalah tolak $\mathrm{H}_{0}$. Hasil belajar sejarah siswa yang diberi pendekatan pembelajaran CTL dan memiliki gaya belajar auditorial lebih rendah dari hasil belajar siswa yang diberi pendekatan pembelajaran konvensional dan memiliki gaya belajar auditorial.

Siswa dengan gaya belajar auditorial lebih tinggi hasil belajarnya bila diberi pendekatan pembelajaran konvensional. Pada pendekatan konvensional siswa menerima materi ajar langsung dari guru. Siswa hanya mencatat bila dianggap perlu dan sesekali bertanya bila tidak mengerti. Siswa dengan gaya belajar auditorial sangat membutuhkan ketegasan seorang guru, karena salah satu cirinya adalah mudah terganggu oleh keributan, sehingga peran seorang guru menjadi dominan dalam pembelajaran termasuk kedispilnan ataupun mencegah kegaduhan siswa dalam belajar.

Keenam, pernyataan untuk hipotesis keenam adalah hasil belajar sejarah antara siswa yang mengikuti pendekatan pembelajaran CTL dan memiliki gaya belajar visual lebih rendah dari hasil belajar sejarah siswa yang mengikuti pendekatan pembelajaran CTL dan memiliki gaya belajar auditorial. Uji tuckey untuk hipotesis keenam adalah tolak $\mathrm{H}_{0}$.

Pendekatan pembelajaran CTL merupakan cara belajar yang melibatkan siswa untuk mencapai tujuan pembelajaran. CTL dengan mendorong siswa untuk aktif dalam mencari bahan ajar, sehingga dapat meningkatkan kemampuan diri dan berguna bagi siswa. Namun demikian, pendekatan pembelajaran CTL tidak dapat berjalan dengan baik bila siswa hanya menerima materi ajar dari seorang guru.

Kemauan untuk membaca dan kemampuan pengembangan diri yang baik bagi siswa dengan gaya belajar visual, akan lebih tinggi bila diberi pendekatan pembelajaran CTL dibanding siswa dengan gaya belajar auditorial. Untuk siswa yang memiliki gaya belajar auditorial, penerapan pendekatan pembelajaran CTL kurang tepat, karena siswa yang memiliki gaya belajar auditorial lebih mudah menerima materi ajar dengan pendekatan konvensional.

Ketujuh, Pernyataan untuk hipotesis ketujuh adalah hasil belajar sejarah antara siswa yang diberi pendekatan pembelajaran konvensional dan memiliki gaya belajar visual lebih tinggi daripada siswa yang mengikuti pendekatan pembelajaran konvensional dan memiliki gaya belajar auditorial. Uji tuckey untuk hipotesis ketujuh adalah tolak $\mathrm{H}_{0}$.

Pendekatan konvensional merupakan pendekatan pembelajaran satu arah. Siswa hanya dapat berkomunikasi dengan guru. Bagi siswa yang memiliki gaya belajar visual, pendekatan konvensional tidak bermanfaat dalam pembelajaran maupun kehidupannya, sedangkan bagi siswa yang memiliki auditorial, pendekatan konvensional tepat karena siswa dapat mendengar seluruh penjelasan guru.

\section{Kesimpulan dan Rekomendasi}

Berdasarkan hasil pengujian hipotesis, kesimpulan penelitian ini sebagai berikut :

Pertama, hasil belajar sejarah antara siswa yang mengikuti pendekatan pembelajaran CTL lebih tinggi daripada siswa yang mengikuit pendekatan pembelajaran konvensional.

Kedua, hasil belajar antara siswa yang memiliki gaya belajar visual lebih tinggi daripada siswa yang memiliki gaya belajar auditorial.

Ketiga, terdapat pengaruh interaksi antara pendekatan pembelajaran dengan gaya belajar terhadap hasil belajar sejarah.

Keempat, hasil belajar sejarah antara siswa yang mengikuti pendekatan pembelajaran CTL dan memiliki gaya belajar visual lebih tinggi daripada siswa yang mengikuti pendekatan pembelajaran konvensional dan memiliki gaya belajar visual.

Kelima, hasil belajar sejarah antara siswa yang mengikuti pendekatan pembelajaran CTL dan memiliki gaya belajar auditorial lebih rendah daripada siswa yang mengikuti pendekatan pembelajaran konvensional dan memiliki gaya belajar auditorial. 
Keenam, hasil belajar sejarah antara siswa yang mengikuti pendekatan pembelajaran CTL dan memiliki gaya belajar visual lebih tinggi daripada siswa yang mengikuti pendekatan pembelajaran CTL dan memiliki gaya belajar auditorial.

Ketujuh, hasil belajar sejarah antara siswa yang mengikuti pendekatan pembelajaran konvensional dan memiliki gaya belajar visual lebih rendah daripada siswa yang mengikuti pendekatan pembelajaran konvensional dan memiliki gaya belajar auditorial.

\section{Rekomendasi}

Berdasarkan kesimpulan dan implikasi yang telah disampaikan, serta dalam rangka pengembangan penelitian dan perbaikan bagi siswa SMA Negeri 35, dikemukakan beberapa saran sebagai berikut :

1. Guru harus memahami dan menguasai pendekatan pembelajaran supaya tujuan pembelajaran dapat dicapai. Pendekatan pembelajaran CTL memiliki pengaruh terhadap hasil belajar sejarah siswa. Untuk itu pendekatan pembelajaran CTL bisa diterapkan di SMA Negeri 35 Jakarta.

2. Gaya belajar siswa harus mendapat perhatian guru. Perbedaan gaya belajar akan berpengaruh terhadap hasil belajar siswa. Untuk itu disarankan, informasi tentang gaya belajar siswa diketahui sejak siswa diterima di SMA Negeri 35.

3. Pendekatan pembelajaran dan gaya belajar berpengaruh terhadap hasil belajar siswa. Disarankan seorang guru untuk menerapkan pendekatan pembelajaran CTL dan konvensional untuk meningkatkan hasil belajar siswa dengan mempertimbangkan gaya belajar siswa.
4. Penerapan salah satu pendekatan pembelajaran dalam ruang kelas bukanlah solusi untuk meningkatkan hasil belajar. Terlebih dengan adanya perbedaan gaya belajar siswa. Untuk itu disarankan supaya guru dalam proses pembelajaran selalu menggunakan 2 pendekatan pembelajaran serta memanfaatkan gaya belajar siswa dalam pelaksanaan proses pembelajaran.

5. Gaya belajar siswa bukanlah konsumsi guru atau pihak sekolah saja, namun siswa tersebut serta orang tua. Informasi tersebut perlu dikomunikasikan kepada orang tua sehingga orang tua juga dapat mengerti dan membantu guru dan pihak sekolah untuk mencapai tujuan pembelajaran secara umum. Setiap siswa yang mengetahui gaya belajarnya, tentunya dapat mempersiapkan diri dalam setiap pembelajaran.

6. Pemilihan waktu belajar juga harus dilakukan penelitian lebih lanjut, supaya apa yang diajarkan disekolah dapat bermanfaat untuk semua siswa tanpa terkecuali.

7. Keterbatasan dalam penelitian ini diharapkan untuk diadakan penelitian sejenis lebih lanjut dengan mempertimbangkan aspek selain gaya belajar. Sehingga penelitian akan lebih komprehensif dan bermanfaat untuk kemajuan SMA Negeri 35 khususnya. 


\section{Daftar Pustaka}

A.M, Sardiman, 2007, Interaksi dan Motivasi Belajar Mengajar, Jakarta : Raja Grafinda Persada.

Ardi, Havid, 2007, Profil Gaya Belajar Bahasa Inggris Siswa SMA Negeri 7 Kota Padang, Padang, Jurnal FBSS Bahasa Sastra dan Seni Vol.1 Edisi JanuariApril 2007

B Uno, Hamzah, 2009, Perencanaan Pembelajaran, Jakarta: Bumi Aksara.

DePorter, Bobbi \& Mike Hernacki. 2013, Quantum Learning: Membiasakan Belajar Nyaman dan menyenangkan, Bandung, PT Mizan Pustaka, 2013.

Hasan, Hamid. "Kurikulum Pendidikan Sejarah Berbasis Kompetensi", Seminar Nasional Ikatan Himpunan Mahasiswa Sejarah Se-Indonesia (Ikahimsi) XII. Semarang, 16 April 2007.

Ningrum DA, Sudiana dan Md. Yudana "Perbedaan pengaruh pembelajaran kontekstual terhadap hasil belajar bahasa inggris antara siswa yang bergaya belajar visual, auditorial dan kinestetik (di SD IT Albanna)" e-journal Volume 4 tahun 2013 Program Pascasarjana Universitas Pendidikan Ganesha Program Studi Administrasi Pendidikan

Nur Ghufron, M dan Rini Risnawati, S. 2013, Gaya Belajar, Kajian Teoretik, Yogyakarta: Pustaka Pelajar.

Panca Astuti, Palupi “Jejak Sejarah Masih Terbelenggu" Litbang Kompas http://edukasi.kompas.com/ read/2010/07/09/05473188/Jejak.Sejarah. Masih, (diunduh 10 Mei 2014, jam 00.16 WIB)

Siregar, Eveline dan Hartini Nara, 2010. Teori Belajar dan Pembelajaran Bogor, Ghalia Indonesia.

Suprihatiningrum, Jamil. 2013. Strategi Pembelajaran: Teori dan Aplikasi Yogyakarta, Ar-Ruzz Media.

Supriyanto, Agus, 2013. Cooperative Learning: Teori dan Aplikasi PAIKEM, Yogyakarta; Pustaka Pelajar. 